\title{
ON AN EQUATION CHARACTERIZING MULTI-JENSEN-QUARTIC MAPPINGS AND ITS STABILITY
}

\author{
Choonkil Park, Abasalt Bodaghi* and Tian-Zhou Xu
}

\begin{abstract}
In this paper, we introduce a new form of the multi-quartic mappings and then unify the system of functional equations defining a multi-Jensen-quartic mapping to a single equation. Applying a fixed point theorem, we study the generalized Hyers-Ulam stability of multi-Jensenquartic mappings. We present a few corollaries corresponding to some known stability outcomes on the multi-quartic and the multi-Jensen-quartic functional equations.
\end{abstract}

Mathematics subject classification (2010): 39B52, 39B72, 39B82.

Keywords and phrases: Banach space, multi-Jensen mapping, multi-Jensen-quartic mapping, multiquartic mapping, Hyers-Ulam stability, hyperstability.

\section{REFERENCES}

[1] T. AoKI, On the stability of the linear transformation in Banach spaces, J. Math. Soc. Japan, 2 (1950), 64-66.

[2] A. BAhyrycz, K. Cieplińs Ki AND J. Olko, On an equation characterizing multi Cauchy-Jensen mappings and its Hyers-Ulam stability, Acta Math. Sci. Ser. B Engl. Ed., 35 (2015), 1349-1358.

[3] A. BAhYRYCZ, K. CieplińsKi AND J. OlKo, On an equation characterizing multi-additivequadratic mappings and its Hyers-Ulam stability, Appl. Math. Comput., 265 (2015), 448-455.

[4] A. BAHYRYCZ AND J. OlKo, On stability and hyperstability of an equation characterizing multiCauchy-Jensen mappings, Results Math., (2018) 73:55, doi.org/10.1007/s00025-018-0815-8.

[5] A. BodaghI, Intuitionistic fuzzy stability of the generalized forms of cubic and quartic functional equations, J. Intel. Fuzzy Syst., 30 (2016), 2309-2317.

[6] A. Bodaghi, Stability of a quartic functional equation, The Scientific World Journal 2014, Art. ID 752146, 9 pages, doi:10.1155/2014/752146.

[7] A. Bodaghi, C. Park and O. T. Mewomo, Multiquartic functional equations, Adv. Difference Equa. 2019, 2019: 312, https://doi .org/10.1186/s13662-019-2255-5.

[8] A. Bodaghi, C. PARK AND S. YUn, Almost multi-quadratic mappings in non-Archimedean spaces, AIMS Mathematics, 5 (5) (2020), 5230-5239. doi:10.3934/math.2020336.

[9] A. Bodaghi, S. M. Moos AVI And H. Rahimi, The generalized cubic functional equation and the stability of cubic Jordan *-derivations, Ann. Univ. Ferrara, 59 (2013), 235-250.

[10] A. Bodaghi, Th. M. Rassias AND A. ZIVARI-KAZEMPour, A fixed point approach to the stability of additive-quadratic-quartic functional equations, Int. J. Nonlinear Anal. Appl., 11 (2020), no. 2, 17 28.

[11] A. Bodaghi AND B. SHOJAEe, On an equation characterizing multi-cubic mappings and its stability and hyperstability, Fixed Point Theory, 22 (2021), no. 1, 83-92.

[12] J. BRZDȨK, Stability of the equation of the p-Wright affine functions, Aequat. Math., 85 (2013), $497-$ 503.

[13] J. BRZdȩK, J. ChudziAK AND Zs. PÁLES, A fixed point approach to stability of functional equations, Nonlinear Anal., 74 (2011), 6728-6732.

[14] J. BRZDȨK AND K. Cieplińs Ki, Hyperstability and Superstability, Abstr. Appl. Anal., 2013, Article ID 401756, 13 pp.

[15] K. CiePlińSKI, On the generalized Hyers-Ulam stability of multi-quadratic mappings, Comput. Math. Appl., 62 (2011), 3418-3426. 
[16] K. CiePLIŃSKI, Generalized stability of multi-additive mappings, Appl. Math. Lett., 23 (2010), 12911294.

[17] K. Cieplińs Ki, Stability of the multi-Jensen equation, J. Math. Anal. Appl., 363 (2010), 249-254.

[18] K. Ciepliński, On multi-Jensen functions and Jensen difference, Bull. Korean Math. Soc., 45 (4) (2008), 729-737.

[19] N. Ebrahimi Hoseinzadeh, A. Bodaghi and M. R. Mardanbeigi, Almost multi-cubic mappings and a fixed point application, Sahand Commun. Math. Anal., 17 no. 3 (2020), 131-143.

[20] S. Falihi, A. Bodaghi AND B. ShojaeE, A characterization of multi-mixed additive-quadratic mappings and a fixed point application, J. Cont. Math. Anal., 55 no. 4 (2020), 235-247.

[21] P. GĂVRUŢA, A generalization of the Hyers-Ulam-Rassias stability of approximately additive mappings, J. Math. Anal. Appl., 184 (1994), 431-436.

[22] D. H. Hyers, On the stability of the linear functional equation, Proc. Natl. Acad. Sci., 27 (1941), 222-224.

[23] K. W. JUn AND H. M. KIM, On the Hyers-Ulam-Rassias stability of a general cubic functional equation, Math. Inequ. Appl., 6 (2) (2003), 289-302.

[24] K. W. JUn AND H. M. KIM, The generalized Hyers-Ulam-Russias stability of a cubic functional equation, J. Math. Anal. Appl., 274 (2) (2002), 267-278.

[25] D. KAnG, On the stability of generalized quartic mappings in quasi- $\beta$-normed spaces, J. Inequ. Appl., 2010, Art. ID 198098, 11 pages, doi:10.1155/2010/198098.

[26] C. PARK AND A. BODAGHI, Two multi-cubic functional equations and some results on the stability in modular spaces, J. Inequ. Appl., 2020 2020:6, https://doi .org/10.1186/s13660-019-2274-5.

[27] W. Prager AND J. SChWAiger, Multi-affine and multi-Jensen functions and their connection with generalized polynomials, Aequationes Math., 69 (1-2) (2005), 41-57.

[28] W. Prager And J. Schwaiger, Stability of the multi-Jensen equation, Bull. Korean Math. Soc., 45 (1) (2008), 133-142.

[29] J. M. RASSIAS, On approximation of approximately linear mappings by linear mappings, J. Funct. Anal., 46 (1982), 126-130.

[30] J. M. RASSIAS, Solution of the Ulam stability problem for quartic mappings, Glasnik Matematicki, 34 (2) (1999), 243-252.

[31] J. M. RASSIAS, Solution of the Ulam stability problem for cubic mappings, Glasnik Matematicki, 36 (1) (2001), 63-72.

[32] TH. M. Rassias, On the stability of the linear mapping in Banach Space, Proc. Amer. Math. Soc., 72 (2) (1978), 297-300.

[33] S. SAlimi AND A. Bodaghi, A fixed point application for the stability and hyperstability of multi-Jensen-quadratic mappings, J. Fixed Point Theory Appl., 2020 22:9, https://doi.org/10.1007/s11784-019-0738-3.

[34] S. Salimi And A. Bodaghi, Hyperstability of multi-mixed additive-quadratic Jensen type mappings, U.P.B. Sci. Bull., Series A, 82 (2020), no. 2, 55-66.

[35] S. M. Ulam, Problems in Modern Mathematics, Science Editions, Wiley, New York, (1964).

[36] T. Z. XU, Stability of multi-Jensen mappings in non-Archimedean normed spaces, J. Math, Phys., 53 (2012), Art. ID 023507; doi:10.1063/1.368474.

[37] T. Z. XU, On the stability of multi-Jensen mappings in $\beta$-normed spaces, Appl. Math. Lett., 25 (2012), 1866-1870.

[38] X. ZhaO, X. YANG AND C.-T. PANG, Solution and stability of the multiquadratic functional equation, Abstr. Appl. Anal., (2013), Art. ID 415053, 8 pp. 